\title{
Utility of monoclonal antibody coagglutination to identify Neisseria gonorrhoeae
}

\author{
H YOUNG, A MOYES \\ From the STD Diagnostic Laboratory, Department of Bacteriology, University Medical School, Edinburgh
}

SUMmaRY The Phadebact monoclonal gonococcus coagglutination test was evaluated with 1367 (996 anogenital and 371 pharyngeal) neisserial isolates from patients who gave positive diagnostic test results for Neisseria gonorrhoeae. The overall correlation with carbohydrate utilisation was $99.7 \%$. The Phadebact test had a specificity of $100 \%(286 / 286)$ and a sensitivity of $99 \cdot 7 \%(1077 / 1080)$. The three non-reactive strains were epidemiologically linked and were of a very unusual serovar. Unlike polyclonal antibody based tests, the monoclonal antibody test provides reliable identification of gonococci from anogenital and pharyngeal sites. Because non-reactive strains are rare, however, negative anogenital isolates from heterosexual patients should be tested biochemically. The use of two reagents comprising separate pools of monoclonal antibodies against gonococcal protein IA and IB permitted the identification of an appreciable number of double infections, which would otherwise have been missed. Genital, rectal, and pharyngeal isolates from the same patient should be identified individually.

The microbiological diagnosis of gonorrhoea is particularly challenging as several anatomical sites may be infected. In general, the greater the number of sites examined the better will be the chance of detecting gonococcal infection. The range of colonising neisseriae other than the gonococcus varies widely between different anatomical sites, however, which has an important bearing on the utility of identification methods. There is currently a wide array of identification tests, which include conventional and rapid sugar degradation tests, new chromogenic substrate identification systems, and immunological methods. ${ }^{1}$ The precise role of the various identification methods remains to be assessed.

Many laboratories experience difficulties with carbohydrate utilisation tests, organisms such as Neisseria meningitidis and Branhamella (Moraxella) catarrhalis being a major cause of diagnostic problems. ${ }^{2}$ The failure of many biochemical identification systems to differentiate between $N$ cinerea and $N$ gonorrhoeae $^{34}$ has serious implications as it may lead to misdiagnosis. ${ }^{5}$ Although $N$ cinerea gave negative results in the Phadebact polyclonal antibody coagglutination test, ${ }^{3}$ occasional cross reactivity with $N$ meningitidis and $N$ lactamica limited the use of this test to isolates from genital sites. ${ }^{6}$ The use of reagents

Address for reprints: Dr $\mathbf{H}$ Young, Department of Bacteriology, University Medical School, Teviot Place, Edinburgh EH8 9A'G

Accepted for publication 16 October 1987 prepared from monoclonal antibodies that recognise epitopes on gonococcal protein $I,{ }^{7}$ provided that the reagents are sufficiently sensitive, should overcome problems of specificity. Immunological identification should thus be reliable for isolates from all anatomical sites.

This study analyses the utility of the Phadebact (Pharmacia Diagnostics, Sweden) monoclonal gonococcus coagglutination test to identify routinely $N$ gonorrhoeae cultured from genital, rectal, and pharyngeal sites.

\section{Patients and methods}

We studied all patients examined for gonococcal infection at the department of genitourinary medicine of Edinburgh Royal Infirmary in September 1985 to December 1986. Material from anogenital and pharyngeal sites was inoculated directly on to modified New York City medium. After being incubated overnight at $37^{\circ} \mathrm{C}$ in an aerobic atmosphere enriched with $5 \%$ carbon dioxide, cultures were examined for oxidase positive Gram negative diplococci (GNDC). Suspect neisserial organisms were then tested by the Phadebact monoclonal gonococcus coagglutination test. Whenever GNDC were isolated from more than one site in the same patient, genital (urethral or cervical), rectal, and pharyngeal isolates were tested separately. 
PHADEBACT MONOCLONAL GONOCOCCUS COAGGLUTINATION TEST

This test kit contains two separate coagglutination reagents, WI and WII/III, which are prepared with pools of monoclonal antibodies reactive with protein IA and protein IB, respectively. ${ }^{7}$

A suspension of suspect organisms was prepared in $0.9 \%$ saline and boiled for 10 minutes. After cooling, the boiled antigen was tested against the WI and WII/ III reagents (unit volume $20 \mu \mathrm{l}$ ): the respective reagents were mixed thoroughly with the antigen by rocking and tilting the slides. Results were read within one minute: a reaction with either the WI or WII/III reagent constituted a positive result and provided instant serogrouping.

If there was insufficient material on the primary plate after overnight incubation a subculture was made and the isolate identified next day.

\section{CONFIRMATORY IDENTIFICATION}

A rapid carbohydrate utilisation test, ${ }^{8}$ modified for performance in microtitre trays, was used to confirm the coagglutination results and to identify nonreactive GNDC.

\section{SEROTYPING}

Isolates were serotyped with two panels of monoclonal antibody coagglutination reagents as described previously. 9

\section{STA TISTICAL ANALYSIS OF RESULTS}

The significance of differences in the results was assessed by the $\chi^{2}$ test with Yates's correction. Predictive values were calculated according to the formula given by Vecchio. ${ }^{10}$

\section{Results}

A total of 888 patients ( 341 women and 547 men) gave positive diagnostic test results, and 43 yielded positive test of cure cultures for Neisseria gonorrhoeae. Infection at more than one site occurred in 147 $(43.2 \%)$ of the 341 women, which resulted in 504 isolates for identification (table 1): 496 of these isolates were tested by coagglutination as well as the rapid carbohydrate utilisation test. The remaining eight isolates from five women (two with genital and rectal infection, one with genital and throat infection, and two with genital infection only) were not available for coagglutination testing.

Infection at more than one site occurred in 10 $(17.5 \%)$ of the 57 homosexual men and in $34(6.9 \%)$ of the 490 heterosexual men, and resulted in 592 isolates for identification (table 2): 584 of these isolates were tested by both coagglutination and the rapid carbo-. hydrate utilisation test. The remaining eight isolates,
Table 1 Pattern of infection in 341 women with positive diagnostic test results

\begin{tabular}{|c|c|c|c|c|}
\hline \multicolumn{3}{|c|}{ Pattern of infection* } & \multirow{2}{*}{$\begin{array}{l}\text { No of } \\
\text { patients }\end{array}$} & \multirow{2}{*}{$\begin{array}{l}\text { No of } \\
\text { isolates }\end{array}$} \\
\hline Genital & Rectal & Pharyngeal & & \\
\hline $\begin{array}{l}\text { Positive } \\
\text { Positive } \\
\text { Positive } \\
\text { Positive } \\
\text { Negative } \\
\text { Negative }\end{array}$ & $\begin{array}{l}\text { Positive } \\
\text { Positive } \\
\text { Negative } \\
\text { Negative } \\
\text { Positive } \\
\text { Negative }\end{array}$ & $\begin{array}{l}\text { Positive } \\
\text { Negative } \\
\text { Negative } \\
\text { Positive } \\
\text { Negative } \\
\text { Positive }\end{array}$ & $\begin{array}{r}16 \\
108 \\
175 \\
23 \\
14 \\
5\end{array}$ & $\begin{array}{r}48 \\
216 \\
175 \\
46 \\
14 \\
5\end{array}$ \\
\hline Total & & & 341 & 504 \\
\hline
\end{tabular}

* Results of culture for Neisseria gonorrhoeae.

Genital = urethral or cervical, or both.

which were from men with urethral infection only, were not available for coagglutination testing.

Throat cultures were taken from $795(89.5 \%)$ of the 888 infected patients. GNDC were isolated from 348 $(43.8 \%)$ of the 795 patients (table 3 ).

Excluding the 101 gonococcal throat isolates included in tables 1 and 2 , but allowing for the 23 patients with dual isolation of neisseriae, a further 270 coagglutination tests were performed. Coagglutination tests were also performed on 17 anogenital isolates (table 4 ) confirmed as being $N$ meningitidis by the rapid carbohydrate utilisation test.

\section{CORRELATION BETWEEN COAGGLUTINATION} AND RAPID CARBOHYDRATE UTILISATION TESTS The results for the coagglutination and rapid carbohydrate utilisation tests applied to the 1367 (996 anogenital and 371 pharyngeal) isolates described above are given in table 5 . The overall agreement between coagglutination and the rapid utilisation tests was $99.8 \%$. Coagglutination had a specificity of $100 \%$ and a sensitivity of $99.7 \%$. The three non-reactive strains were isolated during a restricted time, were epidemiologically linked, and were of the very unusual serovar combination $\mathrm{Bj} / \mathrm{Bro.}^{\text {? }}$

The predictive value of positive coagglutination test

Table 2 Pattern of infection in 57 homosexual (and 490 heterosexual) men with positive diagnostic test results

\begin{tabular}{|c|c|c|c|c|}
\hline \multicolumn{3}{|c|}{ Pattern of infection* } & \multirow{2}{*}{$\begin{array}{l}\text { No of } \\
\text { patients }\end{array}$} & \multirow{2}{*}{$\begin{array}{l}\text { No of } \\
\text { isolates }\end{array}$} \\
\hline Urethral & Rectal & Pharyngeal & & \\
\hline $\begin{array}{l}\text { Positive } \\
\text { Positive } \\
\text { Positive } \\
\text { Negative } \\
\text { Negative } \\
\text { Positive } \\
\text { Negative }\end{array}$ & $\begin{array}{l}\text { Positive } \\
\text { Positive } \\
\text { Negative } \\
\text { Positive } \\
\text { Negative } \\
\text { Negative } \\
\text { Positive }\end{array}$ & $\begin{array}{l}\text { Positive } \\
\text { Negative } \\
\text { Negative } \\
\text { Positive } \\
\text { Positive } \\
\text { Positive } \\
\text { Negative }\end{array}$ & $\begin{array}{rr}1 & \\
1 & \\
17 & (448) \\
3 & \\
6 & (8) \\
5 & (34) \\
24 & \end{array}$ & $\begin{array}{rr}3 & \\
2 & \\
17 & (448) \\
6 & \\
6 & (8) \\
10 & (68) \\
24 & \end{array}$ \\
\hline Total & & & $57(490)$ & $68(524)$ \\
\hline
\end{tabular}

* Results of culture for Neisseria gonorrhoeae. 
Table 3 Range of Gram negative diplococci (GNDC) cultured from the throats of 795 patients

\begin{tabular}{|c|c|c|c|c|}
\hline \multirow[b]{2}{*}{$\operatorname{Organism}(s)$} & \multicolumn{3}{|l|}{ Patient group } & \multirow[b]{2}{*}{$\begin{array}{l}\text { Total } \\
(n=795)\end{array}$} \\
\hline & $\begin{array}{l}\text { Heterosexual men } \\
(n=461)\end{array}$ & $\begin{array}{l}\text { Homosexual men } \\
(n=57)\end{array}$ & $\begin{array}{l}\text { Women } \\
(n=277)\end{array}$ & \\
\hline $\begin{array}{l}\text { Neisseria gonorrhoeae } \\
N \text { gonorrhoeae and } N \text { meningitidis } \\
N \text { meningitidis } \\
N \text { meningitidis } \text { and } N \text { lactamica } \\
N \text { meningitidis } \text { and } N \text { perflava } \\
N \text { lactamica } \\
N \text { flava } \\
N \text { perflava } \\
\text { Branhamella catarrhalis } \\
\text { Not identified* }\end{array}$ & $\begin{array}{r}33 \\
9 \\
148 \\
2 \\
0 \\
5 \\
1 \\
0 \\
0 \\
1\end{array}$ & $\begin{array}{r}13 \\
2 \\
15 \\
0 \\
1 \\
0 \\
0 \\
0 \\
0 \\
0\end{array}$ & $\begin{array}{r}35 \\
9 \\
65 \\
0 \\
0 \\
6 \\
0 \\
1 \\
2 \\
0\end{array}$ & $\begin{array}{r}81 \\
20 \\
228 \\
2 \\
1 \\
11 \\
1 \\
1 \\
2 \\
1\end{array}$ \\
\hline Total & 199 & 31 & 118 & 348 \\
\hline
\end{tabular}

*Failed to grow on subculture.

results was $100 \%$ for GNDC isolated from any site. The predictive value of negative coagglutination test results $\left(\mathrm{PV}^{-}\right)$varied depending on anatomical site, and it decreased as the proportion of gonococci in the total population of GNDC increased. The $\mathrm{PV}^{-}$was $99.9 \%$ for GNDC isolated from the throat, where the incidence of gonococci was $27 \cdot 2 \%(101 / 371$, table 3$)$. The $\mathrm{PV}^{-}$was $98.9 \%$ for GNDC isolated from the rectums of men, where the incidence of gonococci was $78.4 \%(29 / 37$, tables 2 and 4$)$, and $96.5 \%$ for GNDC isolated from the urethras of homosexual men, where the incidence of gonococci was $92.3 \%(24 / 26$, tables 2 and 4). The $\mathrm{PV}^{-}$was $66.8 \%$ for GNDC isolated from the urethras of heterosexual men, where the incidence of gonococci was $99.4 \%(482 / 485$, tables 2 and 4$)$ and $75 \cdot 2 \%$ for GNDC isolated from anogenital sites in women, where the incidence of gonocci was $99 \cdot 1 \%$ (460/464, tables 1 and 4).

\section{DISTRIBUTION OF SEROGROUPS IN ISOLATES FROM DIAGNOSTIC TESTS AND TEST OF CURE CULTURES}

Table 6 shows the distribution of serogroups in 872 patients with positive diagnostic test results. Three of six women with double infection had genital infection with a serogroup WI isolate and rectal infection with

Table 4 Anogenital isolation of Neisseria meningitidis

\begin{tabular}{lllll}
\hline & \multicolumn{3}{l}{ No of isolates from: } & \\
\cline { 2 - 5 } Site & $\begin{array}{l}\text { Heterosexual } \\
\text { men }\end{array}$ & $\begin{array}{l}\text { Homosexual } \\
\text { men }\end{array}$ & Women & Total \\
\hline Urethra & 3 & 2 & 0 & 5 \\
Cervix & 0 & 0 & 1 & 1 \\
Rectum & 0 & 8 & 3 & 11 \\
Total & 3 & 10 & $4^{*}$ & 17 \\
\hline
\end{tabular}

*Three patients (meningococci isolated from cervix and rectum of one woman on same occasion). serogroup WII/III; the converse occurred in the remaining three. The man with a double infection had throat infection with serogroup WI and rectal infection with serogroup WII/III. This represents infection with more than one strain of gonococcus in $4.1 \%(6 /$ 147) of women and one in 10 homosexual men who were infected at more than one site.

Fifteen isolates (shown as serogroup WII/III) reacted with both the WII/III and WI reagent pools, although the reaction was stronger with the WII/III reagent. These isolates were of the highly unusual serovar Av/Bx. ${ }^{911}$

As shown in table 7, WII/III isolates predominated in positive test of cure cultures. In heterosexual patients significantly fewer $\left(\chi^{2}=9.4 ; p<0.01\right)$ isolates from diagnostic tests $(48 \cdot 5 \%, 395 / 815)$ than test of cure cultures $(75 \%, 30 / 40)$ were of serogroup WII/III.

\section{DIRECT SMEAR RESULTS IN RELATION TO}

SEROGROUP OF INFECTING ISOLATE

Of the 341 women with positive diagnostic tests, 285 had valid smear and serogroup results: no smear

Table 5 Correlation between results of rapid carbohydrate utilisation and Phadebact monoclonal gonococcus coagglutination tests

\begin{tabular}{lccr}
\hline \multirow{2}{*}{$\begin{array}{l}\text { Biochemical } \\
\text { identification }\end{array}$} & \multicolumn{2}{l}{ Coagglutination results: } \\
\cline { 2 - 4 } & Positive & Negative & Total \\
\hline Neisseria gonorrhoeae & 1077 & 3 & 1080 \\
N meningitidis & 0 & 268 & 268 \\
N lactamica & 0 & 13 & 13 \\
N flava & 0 & 1 & 1 \\
N perflava & 0 & 2 & 2 \\
Nranhamella catarrhalis & 0 & 2 & 2 \\
No identification* & 0 & 1 & 1 \\
Total & 1077 & 290 & 1367 \\
\hline
\end{tabular}

*One throat isolate failed to grow on subculture. 
Table 6 Distribution of serogroups in 872 patients with positive diagnostic test results

\begin{tabular}{lrrrr}
\hline & \multicolumn{4}{c}{ No (\%) of isolates with serogroup: } \\
\cline { 3 - 5 } Patient group & No & WI & WII/III & WI and \\
\hline Women & $333^{*}$ & $184(55 \cdot 3)$ & $143(42.9)$ & $6(1.8)$ \\
Heterosexual men & $482 \dagger$ & $230(47.7)$ & $252(52 \cdot 3)$ & 0 \\
Homosexual men & 57 & $1(1.8)$ & $55(96.5)$ & $1(1 \cdot 8)$ \\
Total & 872 & $415(47.6)$ & $450(51 \cdot 6)$ & $7(0.8)$ \\
\hline
\end{tabular}

* Of the 341 infected women, isolates from five were not available for coagglutination testing and three were infected with coagglutination negative isolates.

fOf the $\mathbf{4 9 0}$ infected heterosexual men urethral isolates from eight were not available for coagglutination testing.

results were available for $\mathbf{4 2}$ patients, isolates from five patients were not serogrouped, six patients had a mixed infection, and three were infected with coagglutination negative isolates. The incidence $(51.9 \%)$ of serogroup WI in 129 isolates from smear positive patients was not significantly different from the incidence $(57.7 \%)$ in 156 isolates from smear negative patients (data not shown).

\section{DUAL ISOLATION OF NEISSERIA GONORRHOEAE}

AND NEISSERIA MENINGITIDIS FROM THE THROAT As shown in table 3, gonococci were isolated alone in $81(10 \cdot 2 \%)$ of the 795 throat cultures examined, meningococci alone in $231(29 \cdot 1 \%)$, and both gonococci and meningococci in $20(2.5 \%)$ of patients. Based on the 81 positive gonococcal cultures and the 231 positive meningococcal cultures, the theoretical isolation rate for both organisms together is $2.9 \%$ : that is not significantly different from the observed coexistence of $2 \cdot 5 \%$.

\section{Discussion}

The high specificity (100\%) and sensitivity $(99.7 \%)$ of the Phadebact monoclonal gonococcus coagglutination test, combined with the simplicity of its performance, makes it an ideal first line screening test

Table 7 Distribution of serogroups in 43 patients with positive test of cure culture results

\begin{tabular}{lrlr}
\hline & & \multicolumn{2}{l}{$\begin{array}{l}\text { No (\%) of isolates of } \\
\text { serogroup: }\end{array}$} \\
\cline { 2 - 4 } Patient group & No & WI & WII/III \\
\hline Women & 21 & $8(38 \cdot 1)$ & $13(61 \cdot 9)$ \\
Heterosexual men & 19 & $2(10 \cdot 5)$ & $17(89 \cdot 5)$ \\
Homosexual men & 3 & 0 & $3(100)$ \\
Total & 43 & 10 & 33 \\
\hline
\end{tabular}

for characterising neisseriae from primary cultures. In contrast to earlier coagglutination tests with polyclonal antibodies, the absolute specificity of the monoclonal test makes it reliable for differentiating between gonococcal and non-gonococcal neisseriae isolated from any anatomical site. Because of the rare occurrence of a non-reactive serovar, however, coagglutination negative isolates from anogenital sites in heterosexual patients should be confirmed by a biochemical test.

A sensitivity of $99.7 \%$ is probably as high as can be expected, given the immunological diversity of gonococcal isolates. By combining the results of two independently prepared panels of monoclonal antibodies, Sandstrom et al recognised a total of $27 \mathrm{WI}$ serovars and $92 \mathrm{WII} / \mathrm{III}$ serovars in isolates collected in worldwide epidemiological studies. ${ }^{12}$ During a six month period at the beginning of the study we recognised $15 \mathrm{WI}$ and $33 \mathrm{WII} / \mathrm{III}$ serovars, ${ }^{9}$ although this increased to 22 and 58 respectively during the total study period (Coghill and Young, unpublished observations).

The use of separate monoclonal antibody pools to detect isolates bearing protein IA and IB epitopes may help in providing high sensitivity. Evaluations of a coagglutination reagent containing a different set of protein IA and IB monoclonals in a single pool gave poorer results, with sensitivities ranging from $99 \cdot 1 \%{ }^{13}$ to $96.6 \% .^{14}$ is In addition, separate antibody pools would simplify the "tailoring" of reagents to provide optimum detection in distinct geographical regions should that be required. Although our evaluation included most known serovars, a local outbreak caused by a rare non-reactive serovar could substantially alter the performance of the test. The ability to show that non-reactive isolates are of the same rare serovar, however, should aid contact tracing and help prevent non-reactive strains becoming endemic in a given locality.

The use of two separate reagent pools also enabled us to detect infection with more than one strain of gonococcus in $4.1 \%$ of 147 women and one in 10 homosexual men with infection at more than one site. As each case of double infection represented infection at genital and rectal (or pharyngeal) sites with different serogroups, we consider it worthwhile to identify genital, rectal, and pharyngeal isolates from the same patient as separate isolates. Backman et al found two strains of gonococci with different serovars isolated from two $(1 \%)$. of 218 women, two $(7 \%)$ of 28 heterosexual men, and three $(25 \%)$ of 12 homosexual men who yielded two or more gonococcal isolates on the same occasion. ${ }^{16}$ Only two of the seven patients were infected with strains of different serogroups at the same site. The remaining five patients were infected with two strains of the same serogroup but with 
different serovars, which were isolated from different sites. The problems and importance of recognising double infections have been discussed by Bygdeman. ${ }^{11}$

The serogroup of the infecting strain of gonococcus has been correlated with signs and symptoms of urethritis, men infected with serogroup WI strains having fewer leucocytes per high power field than those infected with WII/III strains $(p<0.05) .{ }^{17}$ A similar correlation in female patients might have an important influence on the sensitivity of detecting infection by Gram staining of cervical exudates. This did not appear to be the case. Although serogroup WI isolates were more common $(57 \cdot 7 \%)$ in smear negative patients than smear positive patients $(51.9 \%)$, the difference was not significant. The serogroup of the infecting strain did influence the outcome of treatment, however, with WII/III isolates predominating in positive test of cure cultures $(p<0.01)$. This finding is in keeping with the decreased susceptibility to antibiotics of WII/III isolates. "

The absolute specificity of the monoclonal coagglutination test makes it particularly reliable for excluding non-gonococcal neisseriae and therefore of particular value in clinics where screening for pharyngeal gonorrhoea is performed routinely on patients with anogenital infection.

By performing the coagglutination test direct from the primary isolation plate we were able to detect small amounts of gonococcal antigen in a predominantly meningococcal growth, which enabled us to isolate meningococci and gonococci together as often as expected theoretically. Previous analysis of the isolation of neisseriae from the pharynx showed a significant difference $(p<0.001)$ between the observed and theoretical levels of coexistence of gonococci and meningococci in the pharynx. ${ }^{18}$

Although biochemical test systems such as Gonocheck have the potential to identify nongonococcal neisseriae to species level, ${ }^{1}$ their accuracy remains to be established in large scale clinical trials using direct testing from primary isolation plates. Whereas Brown and Thomas found Gonocheck $100 \%$ specific for 28 isolates of $N$ meningitidis, mainly taken direct from the primary isolation plate, ${ }^{19}$ initial testing of 55 meningococci from primary cultures yielded an accuracy of only $94.5 \%$. In general, the accuracy of Gonocheck is increased by repeat testing, and when this is taken into account the test has a sensitivity in the range of $98.9 \%^{20}$ to $100 \%^{1921-23}$ for $N$ gonorrhoeae. This suggests that Gonocheck would be a useful test for confirming the identity of immunologically nonreactive GNDC from anogenital sites. When used in this way, however, Gonocheck may misidentify $N$ cinerea, which is non-reactive with monoclonal antibodies against gonococcal protein $I$, as a gonococcus. ${ }^{5}$
We conclude that the Phadebact monoclonal gonococcus coagglutination test is a valuable first line test to identify gonococci from all potentially infected sites. Because of temporal and geographical differences in the antigenic profile of circulating gonococci, however, it is important for specialised centres to monitor the serovars of circulating gonococci in representative geographical areas. The identity of all coagglutination negative isolates from anogenital sites in heterosexual patients should be confirmed by biochemical tests, and the serovar of the isolate should be identified. The recent finding of a neisserial isolate with antigenic characteristics of a gonococcus and biochemical properties of a meningococcus $^{24}$ highlights the importance of accurate and reliable identification methods.

\section{References}

1 Young $\mathrm{H}$, Reid KG. Immunological diagnosis of gonococcal infection. In: Young H, McMillan A, eds. Immunological diagnosis of sexually transmitted diseases. New York: Marcel Dekker, 1987:77-116.

2 Arko RJ, Finley-Price KG, Wong KH, Johnson SR, Reising G. Identification of problem Neisseria gonorrhoeae cultures by standard and experimental tests. J Clin Microbiol 1982;15: 435-8.

3 Boyce JM, Mitchell EB. Difficulties in differentiating Neisseria cinerea from Neisseria gonorrhoeae in rapid systems used for identifying pathogenic Neisseria species. J Clin Microbiol 1985;22:731-4.

4 Boyce JM, Mitchell EB, Knapp JS, Buttke TM. Production of ${ }^{14} \mathrm{C}$-labelled gas in BACTEC Neisseria differentiation kits by Neisseria cinerea. J Clin Microbiol 1985;22:416-8.

5 Dossett JH, Appelbaum PC, Knapp JS, Totten PA. Proctitis associated with Neisseria cinerea misidentified as Neisseria gonorrhoeae in a child. J Clin Microbiol 1985;21:575-7.

6 Young H, McMillan A. Rapidity and reliability of gonococcal identification by coagglutination after culture on modified New York City medium. British Journal of Venereal Diseases 1982;58:109-12.

7 Sandström E, Lindell P, Harfest B, Blomberg F, Ryden A-C, Bygdeman S. Evaluation of a new set of Neisseria gonorrhoeae serogroup W-specific monoclonal antibodies for serovar determination. In: Schoolnik GK, Brooks GF, Falkow S, et al, eds. The pathogenic neisseriae. Washington DC: American Society for Microbiology, 1985:13-9.

8 Young H, Paterson IC, McDonald DR. Rapid carbohydrate utilization test for the identification of Neisseria gonorrhoeae. British Journal of Venereal Diseases 1976;52:172-5.

9 Coghill DV, Young H. Serological classification of Neisseria gonorrhoeae with monoclonal antibody coagglutination reagents. Genitourin Med 1987;63:225-32.

10 Vecchio TJ. Predictive value of a single diagnostic test in unselected populations. $N$ Engl J Med 1966;264:1171-3.

11 Bygdeman SM. Polyclonal and monoclonal antibodies applied to the epidemiology of gonococcal infection. In: Young $\mathrm{H}$, McMillan A, eds. Immunological diagnosis of sexually transmitted diseases. New York: Marcel Dekker 1987:117-65.

12 Sandström E, Tam M, Bygdeman S. Antigenic drift of gonococcal protein I as judged by serovar determination. In: Schoolnik GK, Brooks GF, Falkow S, et al, eds. The pathogenic neisseriae. Washington DC: American Society for Microbiology 1985: 13-9. 
13 Lawton WD, Battaglioli GJ. GonoGen coagglutination test for confirmation of Neisseria gonorrhoeae. J Clin Microbiol 1983;18:1264-5.

14 Philip SK, Ison CA, Easmon CSF. Coagglutination identification of Neisseria gonorrhoeae. British Journal of Venereal Diseases 1984;60:66.

15 Young H, Reid KG. Immunological identification of Neisseria gonorrhoeae with monoclonal and polyclonal antibody coagglutination reagents. J Clin Pathol 1984;37:1276-81.

16 Backman M, Ruden A-KM, Bygdeman SM, Jonsson A, Ringertz O, Sandström EG. Gonococcal serovar distribution in Stockholm with special reference to multiple infections and infected partners. Acta Pathol Microbiol Immunol Scand [B] 1985;93:225-32.

17 Ruden A-K, Backman M, Bygdeman S, Jonsson A, Ringertz O, Sandström E. Gonorrhoea in heterosexual men. Correlation between gonococcal W serogroup, Chlamydia trachomatis infection, and objective symptoms. Acta Derm Venereol (Stockh) 1986;66:453-6.

18 Young H, Bain SSR. Neisserial colonisation of the pharynx.
British Journal of Venereal Diseases 1983;59:228-31.

19 Brown JD, Thomas KB. Rapid enzyme system for the identification of pathogenic Neisseria spp. J Clin Microbiol 1985;21:857-8.

20 Wood IA, Young H. Identification of pathogenic Neisseria by enzyme profiles determined with chromogenic substrates. Med Lab Sci 1986;43:24-7.

21 Welborn PP, Uyeda CT, Ellison-Birang N. Evaluation of Gonocheck II as a rapid identification system for pathogenic Neisseria species. J Clin Microbiol 1984;20:680-3.

22 Janda WM, Ulanday MG, Bohnhoff M, LeBeau LJ. Evaluation of the RIM-N, Gonocheck II and Phadebact Systems for the identification of pathogenic Neisseria spp and Branhamella catarrhalis. J Clin Microbiol 1985;21:734-7.

23 Philip A, Garton GC. Comparative evaluation of five commercial systems for the rapid identification of pathogenic Neisseria species. J Clin Microbiol 1985;22:101-4.

24 Hodge DS, Ashton FE, Terro R, Ali AS. Organism resembling Neisseria gonorrhoeae and Neisseria meningitidis. J Clin Microbiol 1987;25:1546-7. 